\title{
Effect of heading on some micronutrients, anti-nutrients and toxic substances in Amaranthus cruentus grown in Minna, Niger State, Nigeria
}

\author{
Amanabo Musa ${ }^{*}$, Johnson A. Oladiran ${ }^{3}$, Matthew I.S. Ezenwa ${ }^{4}$, Helmina O. Akanya ${ }^{2}$, \\ Emmanuel O. Ogbadoyi ${ }^{2}$
}
${ }^{1}$ Department of Biochemistry, Ibrahim Badamasi Babangida University, Lapai, Niger State, Nigeria

\author{
${ }^{2}$ Department of Biochemistry, Federal University of Technology, Minna, Nigeria \\ ${ }^{3}$ Department of Crop Production, Federal University of Technology, Minna, Nigeria \\ ${ }^{4}$ Department of Soil Science, Federal University of Technology, Minna, Nigeria
}

\begin{abstract}
Pot experiments were performed to determine the effect of heading (fruiting) on antinutrients (soluble and total oxalates), toxic substances (cyanide and nitrate) and some micronutrients viz; vitamin $\mathrm{C}, \beta$-carotene (provitamin A) and mineral elements ( $\mathrm{Fe}, \mathrm{Mg}, \mathrm{Cu}, \mathrm{Zn}, \mathrm{Ca}, \mathrm{Na}$ and $\mathrm{K}$ ) in Amaranthus cruentus grown in nitrogen and non-nitogen treated soil. The vegetable leaves were harvested at both market maturity (vegetative phase) and heading (reproductive phase) and were subjected to chemical analysis. Results obtained showed that the vitamin $\mathrm{C}$, cyanide, soluble and total oxalates concentrations in the vegetable were significantly elevated $(p<0.05)$ during heading irrespective of soil nitrogen levels. Nitrate and $\beta$-carotene concentrations decreased significantly $(p<0.05)$ during heading except that the decrease in $\beta$-carotene was not significant in vegetable treated with nitrogen fertilizer. Similarly the result also showed that the $\mathrm{Mg}, \mathrm{Zn}, \mathrm{Ca}$ and $\mathrm{K}$ concentrations were not significantly affected with heading. However, the Fe concentration was increased, while the $\mathrm{Cu}$ and $\mathrm{Na}$ concentrations were reduced significantly $(\mathrm{p}<0.05)$ with heading.The result concludes that harvesting of Amaranthus cruentus at vegetative phase generally reduce the levels of most of the plant toxins and still conserve most of the micronutrients in an amount to meet our dietary requirements.
\end{abstract}

Keywords: Amaranthus cruentus, heading, market maturity, micronutrients, antinutrients, toxic substances.

\section{INTRODUCTION}

There are about 60 species of Amaranthus and several of them are cultivated as leafy vegetables, cereals or ornamental plants (Schippers, 2000; He, 2002; Dhellot et al., 2006). Amaranthus cruentus is an herbaceous annual leafy vegetable that can be produced for fresh market in 4 - 6 weeks after planting. It can be cultivated all the year round depending on the availability of water. This plant requires loamy to sandy loam soil for good yield and does well in soils with high organic matter content (Grubben, 1986). It is a widely distributed genus of short-lived herbs, occurring mostly in temperate and tropical regions. In Nigeria, amaranthus leaves combined with condiments are used to prepare sauce (Oke, 1983; Mepha et al., 2007; Akubugwo et al., 2007).
Amaranthus cruentus is rich in vitamins including $\beta$ carotene (precussor of vitamin A), vitamin B6, vitamin $\mathrm{C}$, riboflavin, and folate, and dietary minerals such as calcium, iron, magnesium, phosphorus, potassium, zinc, copper, and manganese (Makus, 1984; Makus and Davis, 1984; Sussan and Anne, 1988; Stallknecht and Schaeffer, 1993). This vegetable is also rich in lysine, an essential amino acid that is lacking in diets based on cereals and tubers (Schipper, 2000). However, the moderately high content of oxalic acid in the leaves of this vegetable inhibits the absorption of calcium and other mineral elements leading to the formation of kidney stone, oxalaneamia and electrolyte inbalance (Prien, 1991). Amaranthus cruentus under certain conditions have high nitrate content exceeding tolerable limit (Macrae et al., 1997). The vegetable is also known to contain 
some appreciable levels of cyanogenic glycoside which is a respiratory poison.

The levels of the nutrients and toxic substances in the vegetable are known to be influenced by stages of plant development. It is in this direction that the research is designed to investigate the effect of heading (fruiting) on the levels of some micronutrients, antinutrients and toxic substances in the vegetable. This is aiming at determining the stage of plant development that the nutritional potential of Amaranthus cruentus can be fully harness.

\section{MATERIALS AND METHODS}

The study area: The pot experiment was carried out in the nursery of the School of Agriculture and Agricultural Technology, Federal University of Technology, Minna, Niger State of Nigeria.

Niger state has a Savannah climate characterised by maritime air and rainfull is between April and October. During harmattan, dry desert wind blow between November and mid February while night temperature is very low. The geographical location of Minna is longitude $9^{\circ} 40^{\prime} \mathrm{N}$ and latitude $6^{\circ} 30^{\prime} \mathrm{E}$. Minna lies in the Southern Guinea Savannah zone of Nigeria and has a sub-humid semi arid tropical climate with mean annual precipitation of 1200 and $1300 \mathrm{~mm}$. About $90 \%$ of total annual rainfull occurs between the months of June and September. Temperature rarely falls below $22^{\circ} \mathrm{C}$ with peaks of $40^{\circ} \mathrm{C}$ and $30^{\circ} \mathrm{C}$ in February/March and November/December respectively. Wet season temperature average is about $29^{\circ} \mathrm{C}$ (Osunde and Alkassoun, 1998).

Soil sampling and analysis: The soil used in this study was collected from Minna. The soil has been classified as Inseptisol (FDALR, 1985). The bulked sample was collected during the drying season from the field which has been under fallows for about four years. The bulked soil sample was passed through $2 \mathrm{~mm}$ sieve. Sub-sample of the soil was subjected to routine soil analysis using procedure described by Juo (1979). The soil particle sizes were analyzed using hydrometer method; $\mathrm{pH}$ was determined potentiometrically in the water and $0.01 \mathrm{M} \mathrm{CaCl}_{2}$ solution in a 1: 2 soil/ liquid using a glass electrode $\mathrm{pH}$ meter and organic carbon by Walkey-Black method (Juo, 1979). Exchange acidity (E.A H ${ }^{+}$and $\mathrm{Al}^{3+}$ ) was determined by titration method (Juo, 1979). Exchangeable $\mathrm{Ca}, \mathrm{Mg}, \mathrm{K}$ and $\mathrm{Na}$ were leached from the soil sample with neutral $1 \mathrm{~N} \mathrm{NH}_{4} \mathrm{OA}$ solution. Sodium and potassium were determined by flame emission spectrophotometry while $\mathrm{Mg}$ and $\mathrm{Ca}$ were determined by E.D.T.A versenate titration method (Juo, 1979). Total nitrogen was estimated by Macrokjedal procedure and available phosphorus by Bray No 1 method (Juo, 1979). The results of soil analyses are presented in Table 1.

Seeds: The seeds of Amaranthus (Amaranthus cruentus) were obtained from Schools of Agriculture and Agricultural Technology's Farm/Nursery of Federal University of Technology, Minna.

Planting, experimental design and nursery management: About ten seeds of Amaranthus cruentus were planted in a polythene bag filled with $10.00 \mathrm{~kg}$ of top soil and after emergence the seedlings were thinned to two plants per pot. The factorial design was adopted to determine the effect vegetative phase (market maturity) and reproductive phase (heading) in control and nitrogen treated vegetable. Each treatment had 10 pots replicated three times. This gave a total of 60 pots for the vegetable. The seedlings were watered twice daily (mornings and evenings) using watering can and weeded regularly. The experimental area and the surroundings were kept clean to prevent harbouring of pest. The pots were lifted from time to time to prevent the roots of the plants from growing out of the container. Insects were controlled using Sherpa plus (Saro Agro Sciences) four weeks after planting at the rate of $100 \mathrm{ml}$ per 100 litres of water.

Fertilizer treatment : The fertilizer levels for this vegetable are stated below:

$\mathrm{F}_{1}$ (control): $0 \mathrm{~N}$, 30mg $\mathrm{P}_{2} \mathrm{O}_{5} / \mathrm{kg}$ soil and $30 \mathrm{mg} \mathrm{K}_{2} \mathrm{O} / \mathrm{kg}$ soil

$\mathrm{F}_{2}$ : $37 \mathrm{mgN} / \mathrm{kg}$ soil, $30 \mathrm{mg} \mathrm{P}_{2} \mathrm{O}_{5} / \mathrm{kg}$ soil and $30 \mathrm{mg}$ $\mathrm{K}_{2} \mathrm{O} / \mathrm{kg}$ soil

Harvesting: The leaves of vegetable grown in pot experiment in control and nitrogen treated soil were harvested at vegetative phase and at reproductive phase of plant development. The concentration of the nutrients, antinutrients and toxic substances in the leaves were then determined.

Analytical procedure: Both soluble and total oxalates in the samples were determined by titrimetric method of Oke, (1966). The nitrate content in the test samples was determined by the colourimetric method (Sjoberg and Alanka, 1994). Alkaline picrate method was used to analyse the cyanide content in the samples (Ikediobi et al., 1980). The mineral elements ( $\mathrm{Fe}, \mathrm{Cu}, \mathrm{Mg}, \mathrm{Na}$ and $\mathrm{K}$ ) in samples were determined according to the method of Ezeonu et al. (2002). The ascorbic acid content in the 
samples was determined by 2, 6-dichlorophenol indophenols method of Eleri and Hughes (1983). While $\beta$-carotene concentration was determine by ethanol and petroleum ether extraction method (Musa et al., 2010).

Statistical analysis: T-test was used to determine the effect of vegetative phase and reproductive phase in Amaranthus cruentus on of the parameters under investigation.

\section{RESULTS}

Physical and chemical properties of soil: Result of analyses of the soil used for pot experiment is presented in Table 1. The texture class of the soil is sandy loam indicating that the water holding capacity is moderate. The organic matter content, total nitrogen and available phosphorus are low. Sodium and calcium contents are moderate while magnesium and potassium contents are high. The CEC (cation exchange capacity) is moderate while base saturation percentage is high. Soil $\mathrm{pH}$ indicates that the soil is slightly acidic (FAO, 1984; Black, 1985; FDALR, 1985).

Table 1. Some Physical and Chemical Properties of the Soil $(0-20 \mathrm{~cm})$ Used for Pot Experiment

\begin{tabular}{|c|c|}
\hline Parameters & Values \\
\hline Sand (\%) & 74.40 \\
\hline Silt (\%) & 18.00 \\
\hline Clay (\%) & 7.60 \\
\hline $\mathrm{pH}\left(\right.$ in $\left.\mathrm{H}_{2} \mathrm{O}\right)$ & 6.51 \\
\hline $\mathrm{pH}\left(\right.$ in $\left.0.1 \mathrm{M} \mathrm{C}_{\mathrm{a}} \mathrm{Cl}_{2}\right)$ & 5.25 \\
\hline Organic Carbon (\%) & 0.83 \\
\hline Organic Matter (\%) & 1.43 \\
\hline Total nitrogen (\%) & 0.05 \\
\hline Available phosphorus (mg/kg) & 6.69 \\
\hline $\mathrm{K}(\mathrm{cmol} / \mathrm{kg})$ & 0.92 \\
\hline $\mathrm{Na}(\mathrm{cmol} / \mathrm{kg})$ & 0.68 \\
\hline $\mathrm{Mg}(\mathrm{cmol} / \mathrm{kg})$ & 4.80 \\
\hline $\mathrm{Ca}(\mathrm{cmol} / \mathrm{kg})$ & 8.00 \\
\hline E. $A\left(H^{+}+\mathrm{AL}^{3+}\right)(\mathrm{cmol} / \mathrm{kg})$ & 1.50 \\
\hline CEC $(\mathrm{cmol} / \mathrm{kg})$ & 15.90 \\
\hline Base saturation (\%) & 90.57 \\
\hline Texture class & sandy loam \\
\hline
\end{tabular}

*Values represent means of triplicate determinations.
Effect of heading on anti-nutrients and vitamins content: The investigation of the effect of heading on cyanide concentration in Amaranthus cruentus showed that the cyanide content of the vegetable increased significantly during heading irrespective of nitrogen levels. The mean values of cyanide in vegetable at heading in control (308.70 \pm $19.70 \mathrm{mg} / \mathrm{kg})$ and nitrogen applied $(435.00 \pm$ $117.00 \mathrm{mg} / \mathrm{kg}$ ) were significantly higher compared to levels at market maturity $(223.10 \pm 12.00 \mathrm{~g} / \mathrm{kg}$ and $256.28 \pm 9.50 \mathrm{mg} / \mathrm{kg}$ respectively) in Table 2 .

The nitrate content of the vegetable significantly decreased $(p<0.05)$ at heading however, with the application of nitrogen fertilizer, heading had no significant effect $\quad(p>0.05)$ on the nitrate content of the vegetable. The amount of nitrate at market maturity (vegetative phase) and heading (reproductive phase) of the vegetable in control were $17.71 \pm 2.42 \mathrm{~g} / \mathrm{kg}$ and $7.62 \pm 1.00 \mathrm{~g} / \mathrm{kg}$ while the corresponding values obtained with the application of nitrogen fertilizer were $23.41 \pm 2.07 \mathrm{~g} / \mathrm{kg}$ and $18.72 \pm$ $3.40 \mathrm{~g} / \mathrm{kg}$ respectively (Table 2 ).

The mean soluble oxalate concentrations at market maturity and heading in control were $3.11 \pm$ $0.22 \mathrm{~g} / 100 \mathrm{~g}$ and $3.86 \pm 0.25 \mathrm{~g} / 100 \mathrm{~g}$ while the values obtained with the application of nitrogen fertilizer were $2.37 \pm 0.05 \mathrm{~g} / 100 \mathrm{~g}$ and $3.67 \pm 0.18 \mathrm{~g} / 100 \mathrm{~g}$ respectively. This data showed that fruiting significantly elevated $(p<0.05)$ the soluble oxalate content of the vegetable in the control and nitrogen applied (Table 2). Similarly, the total oxalate contents of the vegetable significantly increased $(p<0.05)$ were heading irrespective of the soil nitrogen levels. The mean values of total oxalate at heading in control $(5.27 \pm 0.24 \mathrm{~g} / 100 \mathrm{~g})$ and nitrogen applied (5.04 \pm $0.22 \mathrm{~g} / 100 \mathrm{~g}$ ) were significantly higher compared to levels at market maturity $(4.40 \pm 0.19 \mathrm{~g} / 100 \mathrm{~g}$ and 3.75 $\pm 0.35 \mathrm{~g} / 100 \mathrm{~g}$ respectively) as shown in Table 2 below.

The investigation of the effects of headings on $\beta$ carotene content in Amaranthus cruentus revealed that heading has significant decreasing effects on the provitamin content of the vegetable irrespective of the nitrogen levels. The mean values of $\beta$-carotene at market maturity for controls $(7.45 \pm 0.47 \mathrm{mg} / 100 \mathrm{~g}$ ) and nitrogen applied $(8.04 \pm 0.87 \mathrm{mg} / 100 \mathrm{~g})$ were significantly higher than values $(2.48 \pm 0.33 \mathrm{mg} / 100 \mathrm{~g}$ and $4.86 \pm 0.57 \mathrm{mg} / 100 \mathrm{~g}$ respectively) at heading (Table 2).

The vitamin $C$ content of the vegetable at heading (reproductive phase) was significantly increased as 
campared to the values obtained at market maturity (vegetative phase) irrespective of the soil nitrogen levels. The amount of vitamin $\mathrm{C}$ in Amaranthus cruentus at heading for control (160.50 \pm
$7.10 \mathrm{mg} / 100 \mathrm{~g})$ and nitrogen applied (149.90 \pm $8.20 \mathrm{mg} / 100 \mathrm{~g}$ ) while the corresponding values at market maturity were $94.60 \pm 5.60 \mathrm{mg} / 100 \mathrm{~g}$ and $78.90 \pm 4.50 \mathrm{mg} / 100 \mathrm{~g}$ respectively (Table 2 ).

Table 2. Effect of heading on antinutrients and vitamins content in Amaranthus cruentus

\begin{tabular}{|c|c|c|}
\hline \multirow[t]{2}{*}{ Antinutrients and vitamins } & \multicolumn{2}{|c|}{ Stage of analysis } \\
\hline & Market maturity & Heading \\
\hline Cyanide $(\mathrm{mg} / \mathrm{kg} \mathrm{DW})$, Control & $223.10 \pm 12.00^{\mathrm{a}}$ & $308.70 \pm 19.00^{\circ}$ \\
\hline Cyanide (mg/kg DW), Nitrogen applied & $256.50 \pm 9.50^{\mathrm{a}}$ & $435.00 \pm 117.00^{b}$ \\
\hline Nitrate (g/kg DW), Control & $17.71 \pm 2.42^{b}$ & $7.62 \pm 1.00^{\mathrm{a}}$ \\
\hline Nitrate $(\mathrm{g} / \mathrm{kg} \mathrm{DW})$, Nitrogen applied & $23.41 \pm 2.07^{\mathrm{a}}$ & $18.72 \pm 3.40^{\mathrm{a}}$ \\
\hline Soluble oxalate $(g / 100 g$ DW), Control & $3.11 \pm 0.22^{\mathrm{a}}$ & $3.86 \pm 0.25^{b}$ \\
\hline Soluble oxalate $(\mathrm{g} / 100 \mathrm{~g} \mathrm{DW})$, Nitrogen applied & $2.37 \pm 0.05^{\mathrm{a}}$ & $3.67 \pm 0.18^{b}$ \\
\hline Total oxalate $(g / 100 g$ DW), Control & $4.40 \pm 0.19^{a}$ & $5.27 \pm 0.24^{b}$ \\
\hline Total oxalate $(\mathrm{g} / 100 \mathrm{~g} \mathrm{DW})$, Nitrogen applied & $3.75 \pm 0.35^{\mathrm{a}}$ & $5.04 \pm 0.22^{b}$ \\
\hline$\beta$-carotene $(\mathrm{mg} / 100 \mathrm{~g} \mathrm{FW})$, Control & $7.45 \pm 0.47^{b}$ & $2.48 \pm 0.33^{\mathrm{a}}$ \\
\hline$\beta$-carotene $(\mathrm{mg} / 100 \mathrm{~g} \mathrm{FW})$, Nitrogen applied & $8.04 \pm 0.87^{b}$ & $4.86 \pm 0.57^{\mathrm{a}}$ \\
\hline Vitamin C $\quad(\mathrm{mg} / 100 \mathrm{~g} \mathrm{FW})$, Control & $94.60 \pm 5.60^{\mathrm{a}}$ & $160.50 \pm 7.10^{b}$ \\
\hline Vitamin C (mg/100g FW), Nitrogen applied & $78.90 \pm 4.50^{\mathrm{a}}$ & $149.90 \pm 8.20^{b}$ \\
\hline
\end{tabular}

$\mathrm{DW}=$ Dry weight, $\mathrm{FW}=$ Fresh weight, Control $=$ No nitrogen applied. Values represent means of nine determinations. Row mean values carrying the same superscripts do not differ significantly from each other $(P>0.05)$.

Effect of heading on minerals content: The determinations of the effects of heading on $\mathrm{Fe}$ concentrations in Amaranthus cruentus showed that the $\mathrm{Fe}$ content of the vegetable increased significantly during heading irrespective of nitrogen levels. The mean values of the mineral in vegetable at fruiting in control $(39.76 \pm 2.30 \mathrm{mg} / \mathrm{kg})$ and nitrogen applied $(45.70 \pm 6.50 \mathrm{mg} / \mathrm{kg})$ were significantly higher compared to level at market maturity (33.53 \pm $1.20 \mathrm{mg} / \mathrm{kg}$ and $\quad 24.58 \pm 1.30 \mathrm{mg} / \mathrm{kg}$ respectively (Table 3).
The results obtained from the analysis of $\mathrm{Mg}, \mathrm{Zn}, \mathrm{Ca}$ and $\mathrm{k}$ indicated heading (reproductive phase) had no significant effect on the minerals content in control and nitrogen fertilized vegetable (Table 3). The concentrations of $\mathrm{Cu}$ obtained in the studied vegetable decreased significantly during heading in both control and nitrogen applied. The mean values of the mineral at market maturity for control $(4.55 \pm 0.66 \mathrm{mg} / \mathrm{kg})$ and nitrogen applied (5.05 \pm $0.66 \mathrm{mg} / \mathrm{kg}$ ) were significantly higher than values $(2.78 \pm 0.70 \mathrm{mg} / \mathrm{kg}$ and $2.94 \pm 0.55 \mathrm{mg} / \mathrm{kg}$ respectively) at heading (Table 3 ). 
Similarly, results obtained from the analysis of $\mathrm{Na}$ in the vegetable also showed that heading has a decreasing effect on the mineral content in control and nitrogen treated vegetable. The mineral content at market maturity in control $(11.49 \pm 1.10 \mathrm{mg} / \mathrm{kg})$ and nitrogen fertilized $(11.70 \pm 1.40 \mathrm{mg} / \mathrm{kg})$ were significantly elevated compared to the values (8.81 \pm $0.42 \mathrm{mg} / \mathrm{kg}$ and $8.19 \pm 0.40 \mathrm{mg} / \mathrm{kg}$ respectively) at heading (Table 3 ).

Table 3. Effect of heading on minerals content in Amaranthus cruentus

\begin{tabular}{|c|c|c|}
\hline \multirow[t]{2}{*}{ Minerals } & \multicolumn{2}{|c|}{ Stage of analysis } \\
\hline & Market maturity & Heading \\
\hline Fe (mg/kg), Control & $33.53 \pm 1.20^{\mathrm{a}}$ & $39.76 \pm 2.30^{b}$ \\
\hline $\mathrm{Fe}(\mathrm{mg} / \mathrm{kg})$, Nitrogen applied & $24.58 \pm 1.30^{\mathrm{a}}$ & $45.70 \pm 6.50^{b}$ \\
\hline $\mathrm{Mg}(\mathrm{mg} / \mathrm{kg})$, Control & $26.25 \pm 0.81^{\mathrm{a}}$ & $25.54 \pm 0.94^{\mathrm{a}}$ \\
\hline Mg (mg/kg), Nitrogen applied & $27.12 \pm 1.20^{\mathrm{a}}$ & $25.98 \pm 1.00^{\mathrm{a}}$ \\
\hline Zn (mg/kg), Control & $0.08 \pm 0.01^{\mathrm{a}}$ & $0.05 \pm 0.01^{a}$ \\
\hline Zn (mg/kg), Nitrogen applied & $0.06 \pm 0.01^{\mathrm{a}}$ & $0.06 \pm 0.01^{\mathrm{a}}$ \\
\hline $\mathrm{Cu}(\mathrm{mg} / \mathrm{kg})$, Control & $4.55 \pm 0.66^{\mathrm{b}}$ & $2.78 \pm 0.70^{\mathrm{a}}$ \\
\hline $\mathrm{Cu}(\mathrm{mg} / \mathrm{kg})$, Nitrogen applied & $5.05 \pm 0.66^{b}$ & $2.94 \pm 0.55^{\mathrm{a}}$ \\
\hline $\mathrm{Ca}(\mathrm{mg} / \mathrm{kg})$, Control & $30.28 \pm 0.60^{\mathrm{a}}$ & $29.49 \pm 0.55^{\mathrm{a}}$ \\
\hline $\mathrm{Ca}(\mathrm{mg} / \mathrm{kg})$, Nitrogen applied & $29.49 \pm 0.32^{\mathrm{a}}$ & $30.60 \pm 0.40^{\mathrm{a}}$ \\
\hline $\mathrm{Na}(\mathrm{mg} / \mathrm{kg})$, Control & $11.49 \pm 1.10^{\mathrm{b}}$ & $8.81 \pm 0.42^{\mathrm{a}}$ \\
\hline $\mathrm{Na}(\mathrm{mg} / \mathrm{kg})$, Nitrogen applied & $11.70 \pm 1.40^{\mathrm{b}}$ & $8.19 \pm 0.40^{\mathrm{a}}$ \\
\hline $\mathrm{K}(\mathrm{mg} / \mathrm{kg})$, Control & $209.70 \pm 16.00^{a}$ & $254.30 \pm 22.00^{\mathrm{a}}$ \\
\hline $\mathrm{K}(\mathrm{mg} / \mathrm{kg})$, Nitrogen applied & $219.30 \pm 22.00^{\mathrm{a}}$ & $223.90 \pm 24.00^{a}$ \\
\hline
\end{tabular}

Control = No nitrogen applied. Values represent means of nine determinations. Row mean values carrying the same superscripts do not differ significantly from each other $(P>0.05)$

\section{DISCUSSION}

Significant increase in cyanide concentration in Amaranthus cruentus during heading (fruiting) compared with values at market maturity is in agreement with the report of Cleveland and Soleri (1991) and Carmen et al. (2007). The authors independently observed that the cyanide content in the leaves of Crucifers and cassava increase with the age of the plants respectively. The reason for the increase may likely be that during fruiting, the gene responsible for the synthesis of cyanogenic glycoside may be triggered by some hormonal action associated with fruit initiation and development to produce more of the compound for onward translocation into the fruiting body. This observation is likely to be correct since one of the functions of cyanogenic glycoside in some plants is to protect the plants and their products from predators in order to ensure the continuity of their generation (Peter and Birger, 2002).

The significantly lower nitrate content in Amaranthus cruentus at heading (reproductive phase) compared 
to market maturity (vegetative phase) is in line with report of Richard (1991) and Brown (1993) that young plant in the vegetative stage generally contains more nitrate than mature plants of the same species. Shigeru et al. (2003), Waldemar et al. (2005) and Carmen et al. (2007) also found the same trend in setaria grasses, Anethum graveolens and cassava leaves respectively. This decrease in the nitrate concentration during heading of the vegetable may predict two things; firstly that during this stage of plant development, there could be an increase in the activity of nitrate reductase enzyme leading to an increase in amino acids and proteins required for heading and seeds development. This observation is likely to be correct since there is a report of significant negative correlation between nitrate content in the plant and nitrate reductase activity (Anjana et al., 2007). Secondly, there is likelihood of the translocation of some of nitrate contents in the leaves during fruiting to the developing fruits. This observation is supported by the report of Noggle and Fritz (2006) that during the stage of fruit development, metabolites for cellular synthesis and the growth substances are translocated to the developing fruits from the leaves, stems, and roots. They further stressed that growing fruit is an active sink that diverts and draws water and solutes from other regions of the plant.

Higher oxalates (soluble and total) concentration observed at heading than at market maturity in the Amaranthus cruentus concur with the finding of Waldemar et al. (2005) that older plant had higher oxalates than the younger plant in Anethum graveolens. The reason for this could be that many substances, such as the so - called secondary plant substances (secondary metabolites) accumulate in tissues and organs during aging (Noggle and Fritz, 2006). The elevated levels of cyanide and oxalates recorded at heading of Amaranthus cruentus is enough indication to avoid the inclusion of this popularly consume leafy in our meal at reproductive phase because of the health implications of high ingestion of these toxic substances; cyanide is a culprit in respiratory paralysis while oxalates are responsible for kidney stone and reduction of bioavailability of minerals in the body.

Decrease in $\beta$-carotene content during heading in Amaranthus cruentus agrees with the report of Barros et al. (2007a, b) that the provitamin A concentration decreased in mature fruiting body of mushroom and Lactarius piperatus. The likely reason for the decrease of the compound in the vegetables may be due to the possible translocation of some of its content to the developing fruits and a decline in the content and activity of chlorophyll and associated light absorbing pigments (including caroteniods) following senescence induced by fruit formation and maturation (Noggle and Fritz, 2006).

The increase in the vitamin $\mathrm{C}$ concentration during heading in Amaranthus cruentus though contrary to the observations of Zofia et al. (2006) and Bergquist et al. (2007), agreed with the submission of Chweya (1993) and Chweya and Nameus (1997) that vitamin C content increased significantly with plant age in Gynandropsis gynandra and Cleome gynandra respectively. Barros et al. (2007b) reported the same trend of results in Lactarius piperatus that vitamin C content in Lactarius piperatus was highest at maturity and lowest at immaturity stage. The variations in the vitamin $\mathrm{C}$ concentration reported by different authors during this stage of plant development may have resulted from differences in cultivar (Guillermo et al., 2005; Signh, 2005; Aliyu and Morufu, 2006; Weerakkody, 2006). The increased level of this water soluble vitamin during heading is also not a good reason for inclusion of this vegetable in our meal during this stage of plant development since the vitamin $\mathrm{C}$ concentration at market maturirty is enough to meet adult recommended daily allowance (RDA) of $60 \mathrm{mg}$ ( George, 1999).

Observed significant decrease in some of mineral elements $(\mathrm{Cu}, \mathrm{Na})$ observed in the vegetable during heading compare to higher values at market maturity is in line with finding of Noggle and Fritz (2006), to the effect that during fruit initiation and development, some metabolites for cellular synthesis and growth substances are translocated from the leaves, stems, and roots to the developing fruits. Lanyasunya et al. (2007) observed that the rapid uptake of mineral by plants during early growth and the gradual dilution that occurs as plant matures would have been responsible for the decrease in some of the mineral content during fruiting.

The elevated levels of $\mathrm{Fe}$ in Amaranthus cruentus during heading may likely indicate that the possible physiological and biochemical changes during fruit initiation and development could lead to an increase uptake of the mineral from the soil by the plant for an onward translocation into the fruiting body. This observation is likely to be true since Noggle and Fritz (2006) concluded that the chemical composition of fruit at maturity reflect the presence of materials translocated from other parts of the plant as well as 
materials formed by metabolic activities of the fruit tissues.

\section{CONCLUSION:}

We conclude that harvesting of the Amaranthus cruentus at vegetative phase (market maturity) generally reduce the levels of most of the plant toxins and still conserve most of the micronutrients in an amount to meet the dietary requirements. This will reduce the health problems associated with high levels of antinutrients and toxic substances in the vegetables and improve the general well being of individual. This will in turn lead to increase in productivity.

\section{REFERENCES}

Akubugwo, I.E., Obasi, N.A., Chinyere, G.C. and Ugbogu, A.E (2007). Nutritional and chemical value of Amaranthus hybridus L. leaves from Afikpo, Nigeria. African Journal of Biotechnology. 6 (24): 2833 - 2839.

Aliyu, H.M. and Morufu, A.I (2006). Proximate analysis of some leafy vegetables (Roselle, jute and bitter leaf). International Journal of Foods and Agricultural Research. 3 (1): 194 - 198.

Anjana, S.U., Muhammed, I. and Abrol. Y.P (2007). Are nitrate concentrations in leafy vegetables within safe limits? Current Science. 92(3): $355-360$.

Barro, L., Baptista, P., Estervinho, L.M. and Ferreira, I.C (2007a). Effect of fruiting body maturity stage on chemical composition and antimicrobial activity of Lactarius sp. Mushroom. Agric. Chem. 55 (21): 8766 8771.

Barros, L., Baptista, P. and Ferreira, I.C (2007b). Effect of Lactarius piperatus fruiting body maturity stage on antioxidant activity measured by several biochemical assays. Food and Chemical Toxicology. 45 (9): 1731 1737.

Bergquist,S.A.M., Gertsson, U.E. and Olsson, M.E (2007). Biotive compounds and visual quality of baby spinach - changes during Plant growth and storage. International Society of Horticutural Science. http;www.actahort. org/members/show pdf? Booknrarnr=744_37.

Brown, J.R (1993).Nitrate in Soils and Plants: MU Extention. http;//extention.missouri.edu/xplor/agguides/agchem/g 09804.htm.

Carmen, W., Angelita, D.S. and Henrique, V. P (2007). Antinutrients in the cassava (Manihot esculenta crantz) leaf powder at three ages of the plant. Ciencia e Technologia de Alimentos. http;//www.Scielo.br/Scielo.php? Script = Sci- arttext \& pid = S 0101- 20612007000100019 \& Ing = e ---
Chweya, J. A (1993). Genetic enhancement of indigenous vegetables in Kenya. Field and laboratory experience report. Kengo, Nairobi. http://www.ipgri.cgiar.org/publications/HTMLpublication s/500/ch12.htm

Chweya, J.A and Nameus, A.M (1997). Cats whiskers (Cleome gynandra L). Promoting the conservation and use of underutilized and neglected crops. II. Institute of plant genetics and crop plant research. Gatersleben / International plant Genetic Resources Institute, Rome, Italy. Pp 18 - 21

Cleveland, D.A. and Soleri, D (1991). Food from dry land garden: An ecological, nutritional and social approach to small scale house food production. Publ. Centre for People. Food and Environment (CPFE) USA. Pp 26 28.

Dhellot, J.R., Matouba, E., Nzikou, J.M., Safou, D.G., Linder, N.M., Desobry, S. and Parmentier, M (2006). Extraction, chemical composition and nutritional characterization of vegetable oils: Case of Amaranthus hybridus (Vol 1 and 2) of Congo Brazaville. African Journal of Biotechnology. 5 (11): 1095 - 1101.

Eleri, T. and Hughes, R.E (1983). Foliar ascorbic acid in some Angiosperms. Phytochem. 2 (11): 2493.

Ezeonu, F.C., Musa, A., Stanly, C.D., Oswald, C.E (2002). Iron and zinc status in soils, water and stable food cultivars in Itakpe, Kogi state of Nigeria. The Environmentalist. 22; 237-240.

FDALR (1985). The reconnaissance soil survey of Niger State. Soil report. Federal Department of Agricultural Land Resources.

George, D.P.R (1999). Newlife style: Enjoy it. Editorial Safeliz, Spain. Pp 39, $65-100$.

Grubben, G.J.H (1986). The cultivation of amaranth as a tropical leafy vegetables communication (67). Department of Agricultural Research. Royal Tropical Institute Amsterdam. Pp 11-12.

Guillermo, G., Mauricio, V. and Amy, T.N (2005). The influence of cultivar and plant age on the chemical composition of field grown cassava leaves and roots. Plant Foods for Human Nutrition. 35 (2): 109 - 119.

He, H.P., Cai, Y., Sun, M. and Corke, H (2002). Extraction and purification of squalene from amaranthus grain, $J$. Agric Food Chem. 50 (2): 368 - 372.

Ikediobi, C.O., Onyia, G.O.C and Eluwah, C.E (1980). A rapid and inexpensive enzymatic assay for total cyanide in cassava (Manihot esculenta crantz) and cassava product. Agric. Biol. Chem. 44: 2803 - 2808.

Juo, A.S.R (1979). Selected methods of soils and plants analysis: Farming systems program - Manual series No. 1. Ibadan, IITA. Pp 3-15. 
Lanyasunya, T.P., Wang, H.R., Kariuki, S.T., Kuria, D.M., Check, A.L. and Mukisira, E.A (2007). Effect of fruiting on the mineral content of hair vetch (Vicia villosa). Tropical and Subtropical Agroecosystems. 7: 53 - 58.

Macrae, R., Robinson, R.K. and Sadler, M.J (1997). Encyclopaedia of Food Science, Food Technology and Nutrition. New York, Academic Press. 5: 3240 - 3249, $7: 4715-4757$.

Makus, D.T. and David, D.R (1984). A mid-summer crop for fresh green or canning-vegetables amaranth. Ark. Farm Res. May - June.

Makus, J.D (1984). Evaluation of amaranth as a potential green crop in the mid-south. Hort. Science 19: 881 883.

Mepha, H.D., Eboh, L. and Banigbo, D.E.B (2007). Effect of processing treatments on the nutritive composition and consumer acceptance of some Nigerian edible leafy vegetables. African Journal of Food Agricultural Nutrition Development. 7 (1): 1 - 18.

Musa. A., Ezenwa. M I S., Oladiran. J A., Akanya. H O and Ogbadoyi. E O (2010). Effect of soil nitrogen levels on some micronutrients, antinutrients and toxic substances in Corchorus olitorius grown in Minna, Nigeria. African Journal of Agricultural Research. 5 (22): 3075 - 3081 .

Noggle, G.R.and Fritz, J.G (2006). Introductory plant physiology. Prentice - Hall of Indian Private Limited. $2^{\text {nd }}$ edition. Pp $570-609$.

Oke, L.O (1966). Composition of some Nigeria leafy vegetables. Journal of the American Dietetic Association. 53: $130-132$.

Oke, O.L (1983). Amaranthus In "Handbook of tropical foods" Chan Jr, H.T. Edition. Marcel-Dekker, Inc. New York. Pp $1-2$.

Osunde, A.O. and Alkassoum, A (1998). Growth, natural nodulation, and nutrient yield of selected multipurpose tree species in a Nigerian moist savana soil. Agronomic Africaine Numero Special. 1: 361 - 373.

Peter, K.B. and Birger. L.M (2002). Dhurrin synthesis in sorghum is related at the transcriptional level and induced by nitrogen fertilization in order plants. Plants physiology. 129: 1222 - 1231.
Prien, J.T (1991). Dietary changes and the incidence of urinary Calculi in the U.K. between 1986 and 1991. J. Chron. Dis. 32: $469-476$.

Richard, D.W (1991). Cooperative Extension Service: Cooperative Extension work acts may 8 and June 30, 1914, as amended, Kansas State University, County Extension Councils. Extension Districts and U.S. Department of Agriculture Cooperating.

Schippers, R.R (2000). African indegenous vegetables: An overview of the cultivated species. University Greenwwish. England. Pp 193 - 205.

Shigeru. M., Noriko. Y. and Keerthis, S.G (2003). Simple capillary electrophoretic determination of soluble oxalate and nitrate in forage grasses. Journal of Vet. Diagn Invest. 15: 480 - 483.

Singh, P.P (2005). Influence of light intensity, fertilizers and Salinity on oxalate and mineral concentration of two vegetables (Chenopodum Album L. and Chemopodium amaranthicolor L.) Journal of Plant Foods for Nutrition. Springer Nether lands. 24 (2): 115 $-125$.

Sjoberg, A.M.K. and Alanko, T.A (1994). Spectrophotometric determination of nitrate in baby food: Collaborative study. Journal of AOAC International. 77 (2): $\quad 425-430$.

Stallknecht, G.F. and Schulz-Schaeffer, J.R (1993). Amaranth rediscovered. In. J. Janick and J.E. Simon edition. New Crops. Wiley Crops Wiley, New York.

Sussan, M. and Anne, P (1988). Tropical and sub-tropical food. $2^{\text {nd }}$ edition. Macmillan Publisher. England. Pp $102-106$

Waldemar, K., Zofia. L. and Piotr., G (2005). The level of nitrates, nitrites and oxalates in different usable parts of Dill (Anethum graveolens L.) Depending on plant height. Acta Sci. Pol. Technol. Aliment.4 (1): 93 - 102.

Weerakkody, W.A.P (2006). Nutritional value of fresh leafy vegetables as affected by pre-harvest factors. International Society for Horticultural Science. 604(2): $120-132$.

Zofia, L., Waldemar, K. and Anna, K (2006). Content of vitamin $\mathrm{C}$, caroteniods, chlorophylls and polyphenols in green parts of dill (Anethum graveolens $L$ ) depending on plant height. Journal of Food Composition and Analysis. 19 (2-3): 134 - 140. 